\title{
ENSAT Stage I Adrenal Cortex Carcinoma
}

National Cancer Institute

\section{Source}

National Cancer Institute. ENSAT Stage I Adrenal Cortex Carcinoma. NCI Thesaurus. Code C104031.

Stage I includes: T1, N0, M0. Tumor $5 \mathrm{~cm}$ or less in greatest dimension. The tumor has not invaded the surrounding tissues or organs and has not spread to lymph nodes or distant organs or tissues. (ENSAT 7th Ed, 2009) 